\title{
PARASITOSIS IN WILD FELIDS OF INDIA: AN OVERVIEW
}

\section{Aman Dev Moudgil ${ }^{1}$, Lachhman Das Singla ${ }^{2}$ \& Pallavi $^{3}$}

${ }^{1,2}$ Department of Veterinary Parasitology, College of Veterinary Science, GADVASU, Ludhiana, Punjab 141004, India ${ }^{3}$ School of Public Health and Zoonoses, GADVASU, Ludhiana, Punjab 141004, India

${ }^{1}$ moudgil.aman@gmail.com, ${ }^{2}$ Idsingla@gmail.com (corresponding author), ${ }^{3}$ upadhyayapallavi.31@gmail.com

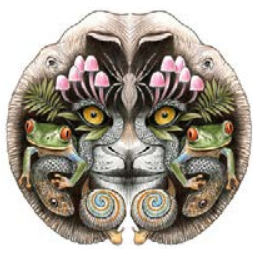

ISSN 0974-7907 (Online) ISSN $0974-7893$ (Print)

OPEN ACCESS

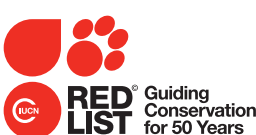

Abstract: Being a tropical country, India provides an ideal environment for the development of parasites as well as for vector populations resulting in a high degree of parasitism in animals and humans. But only a few detailed studies and sporadic case reports are available on the prevalence of parasites in captive wild animals, and the knowledge of parasites and parasitic diseases in wild animals is still in its infancy. The family felidae comprises the subfamily felinae and pantherinae, and within those are all large and small cats. Most of the available reports on parasites in felids describe helminthic infections, which caused morbidities and occasional mortalities in the infected animals. The parasites most frequently found include the nematodes Toxocara, Toxascaris, Baylisascaris, Strongyloides, Gnathostoma, Dirofilaria and Galonchus, the trematode Paragonimus and the cestodes Echinococcus and Taenia. Almost all the studies identified the parasitic stages by classical parasitological techniques and only a few new studies confirmed the species using molecular techniques. Amongst the protozoan parasitic infections reported in felids: babesiosis, trypanosomiasis and coccidiosis are most commonly found. Most of the parasite species found in felids are transmissible to humans (zoonosis) and therefore have public health significance. Routine monitoring of the presence of parasites in captive wild felids is imperative for the formulation and implementation of measures to prevent and control parasitic infections and the transmission of these parasites to humans. This review summarizes the available reports and highlights deficient areas, which require further systematic investigation.

Keywords: Felids, parasitosis, wildlife, zoonosis

DOI: http://dx.doi.org/10.11609/JoTT.04236.7641-8

Editor: Ulrike Streicher, Wildlife Veterinarian / Wildlife Management Consultant, Eugene, USA.

Date of publication: 26 August 2015 (online \& print)

Manuscript details: Ms \# o4236 | Received 10 February 2015 | Final received 12 June 2015 | Finally accepted 20 July 2015

Citation: Moudgil, A.D., L.D. Singla \& Pallavi (2015). Parasitosis in wild felids of India: an overview. Journal of Threatened Taxa 7(10): 7641-7648; http://dx.doi. org/10.11609/JoTT.04236.7641-8

Copyright: @ Moudgil et al. 2015. Creative Commons Attribution 4.0 International License. JoTT allows unrestricted use of this article in any medium, reproduction and distribution by providing adequate credit to the authors and the source of publication.

Funding: None.

Competing interests: The authors declare no competing interests.

Author Details: AMAN DEV MOUDGIL has carried out detailed study on prevalence and management of parasitic infections in captive wild animals and has recently concluded PhD with the same objective in the field of veterinary parasitology. LACHHMAN DAS SINGLA possesses more than 21 years of teaching, research and extension experience in the field of veterinary parasitology, especially in wildlife parasitology. PALLAVI carries experience in research on the diseases of zoonotic and public health significance.

Author Contribution: All the authors contributed as per their sequence in the manuscript:ADM - written the manuscript, LDS - reviewed and edited the manuscript, $P$ - helped in writing and collection of literature. 


\section{INTRODUCTION}

There are around 250 species of wild carnivores distributed throughout the globe, out of which eight families comprising 60 species are found in India (Acharjyo 2002). The latin word "carnivores" means 'meat-eater' and the order Carnivora includes animals which predominantly eat meat as well as animals that occasionally eat meat and are in fact omnivores, such as bears and civets. Carnivores are kept in zoological gardens or wildlife parks for the purpose of education, exhibition and gene conservation (Khatun et al. 2014). The health of these animals requires special attention as conditions in captivity facilitate development of viral, bacterial and parasitic infections. These are of major concern as they pose a serious threat to the animals and persons who come in contact with the animals, like zoo keepers and veterinarians. In their natural habitat felids range over large areas, have low parasitic exposure and consequently low genetic resistance against parasitic infections (Raja et al. 2014). In captivity, for example in zoological gardens, the problem of parasitic infections in these animals can aggravate and pose a serious threat (Muoria et al. 2005). Parasitic infections are not only responsible for the morbidities of animals but heavier infections may actually be fatal (Chhabra \& Pathak 2013). There is a woeful paucity of detailed studies of parasitic diseases of wild animals in India and mostly only case reports are available. This review compiles all available case reports and other studies of the parasitic diseases of wild felids in India.

\section{METHODS}

A majority of the infections found in wild felids in captivity are helminthic infections. Therefore, we have analysed the incidences of parasitic infections by species. All the literature included in the analyses is listed and organized as per parasite species in the tables below.

\section{NeMATOdE INFECTIONS \\ Toxocara infections}

Toxocara, which were not identified to species level, have been found both during regular faecal examination and during necropsies in different parts of India. Health problems caused by various species of Toxocara were found predominantly in younger animals (Kumar \& Rao 2003). Parasite eggs and adult parasites were recovered from Leopard Cats, Bengal Tigers, Asiatic Lions, Leopards and Snow Leopards. Necropsy, coprology and molecular identification reports of the parasites in wild felids are listed in Table 1.

\section{Toxascaris leonina infections}

Toxascaris leonina is an intestinal parasite commonly found in domestic cats, dogs and foxes, but related wild species also frequently get infected with the parasite

Table 1. Reports of Toxocara species in wild felids

\begin{tabular}{|c|c|c|}
\hline Species of the animal & Procedure of recovery & Locality (References) \\
\hline \multirow[t]{2}{*}{ Jungle Cat Felis chaus } & Necropsy & $\begin{array}{l}\text { Baranga Zoo, Odisha (Patnaik \& Acharjyo 1970), Assam State Zoo, Guwahati (Nashiruddullah \& } \\
\text { Chakraborty 2001) }\end{array}$ \\
\hline & Coprology & $\begin{array}{l}\text { Thiruvananthapuram Zoo (Vardharajan \& Pythal 1999), Thrissur Zoo (Varadharajan et al. 2001), in } \\
\text { wild, Kerala (Mahali et al. 2010), Nandankanan Zoo, Odhisha (Mahali et al. 2010) }\end{array}$ \\
\hline $\begin{array}{l}\text { Golden Cat Catopuma } \\
\text { temminckii }\end{array}$ & Coprology & Baranga Zoo (Patnaik \& Acharjyo 1970) \\
\hline $\begin{array}{l}\text { Leopard Cat Prionailurus } \\
\text { bengalensis }\end{array}$ & Necropsy & in wild, Kerala (Easwaran et al. 2003) \\
\hline \multirow[t]{2}{*}{$\begin{array}{l}\text { Royal Bengal Tiger Panthera } \\
\text { tigris tigris }\end{array}$} & Coprology & $\begin{array}{l}\text { Baranga Zoo (Patnaik \& Acharjyo 1970), Thiruvananthapuram Zoo (Varadharajan \& Pythal } \\
\text { 1999), Rajkot Zoo (Parsani et al. 2001), MC Zoological Park, Chhatbir, Punjab (Singh et al. 2006), } \\
\text { Nandankaran Zoo (Mahaliet al. 2010) }\end{array}$ \\
\hline & Necropsy & Assam State Zoo (Nashiruddullah\& Chakraborty 2001) \\
\hline \multirow[t]{2}{*}{$\begin{array}{l}\text { Asiatic Lion Panthera leo } \\
\text { persica }\end{array}$} & Coprology & $\begin{array}{l}\text { Zoological Park, Coimbatore (Varadharajan \& Kandasamy 2000), Thrissur Zoo (Varadharajan et al. } \\
\text { 2001), Rajkot Zoo (Parsani et al. 2001), captive at Ramgiri Estate, Wayanad (Ravindran et al. 2006), } \\
\text { MC Zoological Park (Singh et al. 2006), Nandankanan Zoo (Mahali et al. 2010), Nandan Van Zoo, } \\
\text { Chhatissgarh (Thawait et al. 2014) }\end{array}$ \\
\hline & $\begin{array}{l}\text { Coprology/ Molecular } \\
\text { identification }\end{array}$ & Nehru Zoological Park, Hyderabad (Pawar et al. 2012) \\
\hline \multirow{2}{*}{ Leopard Panthera pardus } & Coprology & $\begin{array}{l}\text { Rajkot Zoo (Parsani et al. 2001), M.C. Zoological Park (Singh et al. 2006), Nandankanan Zoo (Mahali } \\
\text { et al. 2010), Nandan Van Zoo (Thawait et al. 2014) }\end{array}$ \\
\hline & Necropsy & Assam State Zoo (Nashiruddullah \& Chakraborty 2001) \\
\hline Snow Leopard Panthera uncia & Coprology & Darjeeling Zoo (Maity et al. 1994) \\
\hline
\end{tabular}


and serve as definitive hosts for this species. Cases of various wild felids infected with $T$. leonina, including Jungle Cat Felis chaus, Royal Bengal Tigers Panthera tigris tigris, Asiatic Lions Panthera leo persica and Leopards Panthera pardus were documented from different parts of India. The parasite was found during coprology and at necropsy, but molecular confirmation of the parasite was carried out only once by Pawar et al. (2012) in Nehru Zoological Park, Hyderabad. The reports of this parasite from different zoological gardens of the country are listed in Table 2.

\section{Ancylostoma (Hookworm) infections}

Hookworm species including Ancylostoma and Uncinaria species have been recorded from wild felids throughout the globe and are currently known to occur in more than 24 wild animal species. Ten species of hookworms belonging to three genera of the family Ancylostomatidae have been found in a variety of felids.
In the past, several new species of Ancylostomatidae were described from India: Maplestone (1939) described Uncinaria felidis from a Leopard Cat in Kolkata and Rao (1939) described Arthrocephalus gambiensis from Common Mongoose in Chennai. Dubey \& Pande (1961) found that $A$. caninum could infect Jungle Cats by entering the lumen of the intestine from outside through the serosa. In 1985, Agarwal found Ancylostoma paraduodenale in the Asiatic Lion in India. The species was reported in felids for the very first time in 1951 by Biocca. This hookworm causes cutaneous larva migrans in humans, thus possesses significant zoonotic potential. The different reports of the hookworms are listed in Table 3.

\section{Dirofilaria immitis infections}

This parasite is also known as heartworm of dogs and requires mosquitoes as vectors for its transmission. The definitive host of the parasite is the dog, but it has also

Table 2. Reports of Toxascaris leonina in wild felids

\begin{tabular}{|c|c|c|}
\hline Species of the animal & Procedure of recovery & Locality (Reference) \\
\hline Jungle Cat Felis chaus & Coprology & Nandankanan Zoo (Mahali et al. 2010) \\
\hline \multirow[t]{2}{*}{$\begin{array}{l}\text { Royal Bengal Tiger } \\
\text { Panthera tigris tigris }\end{array}$} & Coprology & $\begin{array}{l}\text { Lucknow and Delhi zoos (Chauhan et al. 1973), Lucknow and Kanpur zoos, Uttar Pradesh (Gaur et al. } \\
\text { 1979; Arora \& Das 1988), Maharajbagh Zoo, Nagpur (Dhoot et al. 2002), MC Zoological Park (Singh et } \\
\text { al. 2006), Nandankanan (Mahali et al. 2010) }\end{array}$ \\
\hline & Necropsy \& vomitus & Assam State Zoo (Nashiruddullah \& Chakraborty 2001) \\
\hline \multirow[t]{3}{*}{$\begin{array}{l}\text { Asiatic Lion } \\
\text { Panthera leo persica }\end{array}$} & Coprology & $\begin{array}{l}\text { Lucknow Zoo (Chauhan et al. 1973), Lucknow and Kanpur zoos (Gaur et al. 1979), Bikaner Zoo (Tanwar } \\
\text { et al. 1984), Thiruvananthapuram Zoo (Varadharajan \& Pythal 1999), Thrissur Zoo (Varadharajan et al. } \\
\text { 2001), Maharajbagh Zoo (Dhoot et al. 2002), MC Zoological Park (Singh et al. 2006), captive at Ramgiri } \\
\text { Estate, Wayanad (Ravindran et al. 2006), Nandankanan Zoo (Mahali et al. 2010) }\end{array}$ \\
\hline & Necropsy & Assam State Zoo (Nashirduddullah \& Chakraborty 2001) \\
\hline & $\begin{array}{l}\text { Coprology/ Molecular } \\
\text { identification }\end{array}$ & Nehru Zoological Park (Pawar et al. 2012) \\
\hline $\begin{array}{l}\text { Leopard } \\
\text { Panthera pardus }\end{array}$ & Coprology & $\begin{array}{l}\text { Lucknow and Delhi zoos (Chauhan et al. 1973), Thiruvananthapuram Zoo (Varadharajan \& Pythal } \\
\text { 1999), Maharajbagh Zoo (Dhoot et al. 2002), Bannerghata Biological Park, Bengaluru (Chandranark et } \\
\text { al. 2005) }\end{array}$ \\
\hline
\end{tabular}

Table 3. Reports of hookworms from wild felids of different parts of India

\begin{tabular}{|c|c|c|}
\hline $\begin{array}{l}\text { Species of the } \\
\text { animal }\end{array}$ & $\begin{array}{l}\text { Procedure of } \\
\text { recovery }\end{array}$ & Locality (Reference) \\
\hline Jungle Cat & Coprology & Coimbatore Zoo (Varadharajan \& Kandasamy 2000), Nandankanan Zoo (Mahali et al. 2010) \\
\hline \multirow{2}{*}{ Leopard Cat } & Necropsy & Baranga Zoo, Odhisha (Patnaik \& Acharyjyo 1970), Nandankanan Zoo (Rao \& Acharjyo 1984) \\
\hline & Coprology & Lucknow and Kanpur zoos (Gaur et al. 1979) \\
\hline \multirow[t]{2}{*}{$\begin{array}{l}\text { Royal Bengal } \\
\text { Tiger }\end{array}$} & Coprology & $\begin{array}{l}\text { Lucknow and Delhi zoos (Chauhan et al. 1973), Lucknow Zoo, Uttar Pradesh (Gaur et al. 1979), Thiruvananthapuram Zoo } \\
\text { (Varadharajn \& Pythal 1999), Rajkot Zoo (Parsani et al. 2001), Maharajbagh Zoo (Dhoot et al. 2002), MC Zoologial Park } \\
\text { (Singh et al. 2006), Nandankanan Zoo (Mahali et al. 2010) }\end{array}$ \\
\hline & Necropsy & Vandalur Zoo, Tamil Nadu (Thilakan et al. 2007) \\
\hline \multirow[t]{2}{*}{ Asiatic Lion } & Coprology & $\begin{array}{l}\text { Rajkot Zoo (Parsani et al. 2001), Thrissur Zoo (Varadharajan et al. 2001), Maharajbagh Zoo (Dhoot et al. 2002), MC } \\
\text { Zoological Park (Punjab) (Singh et al. 2006), Nandankanan Zoo (Mahali et al. 2010) }\end{array}$ \\
\hline & Necropsy & Zoological Park, Gwalior (Agrawal \& Chauhan 2001) \\
\hline Leopard & Coprology & $\begin{array}{l}\text { Nehru Zoo (Suresh et al. 2000), Thrissur Zoo (Varadharajan et al. 2001), MC Zoological Park (Singh et al. 2006), } \\
\text { Nandankaran Zoo (Mahali et al.2010), Kerala Zoo (Ravindran et al. 2011) }\end{array}$ \\
\hline
\end{tabular}


Table 4. Reports of $D$. immitis infections in wild felids

\begin{tabular}{|l|l|l|}
\hline $\begin{array}{l}\text { Species of the } \\
\text { animal }\end{array}$ & $\begin{array}{l}\text { Procedure } \\
\text { of recovery }\end{array}$ & Locality (Reference) \\
\hline Golden Cat & Necropsy & Nandankanan Zoo (Rao \& Acharjyo 1984, 1991) \\
\hline Royal Bengal Tiger & Necropsy & Nandankanan Zoo (Rao \& Acharjyo 1993), Birsa Biological Park, Ranchi (Gupta et al. 1999; Haque \& Ahmed 2002) \\
\hline Asiatic Lion & Necropsy & $\begin{array}{l}\text { Nandankanan Zoo (Rao \& Acharjyo 1993), Birsa Biological Park (Gupta et al. 1999; Haque \& Ahmed 2002), Assam State } \\
\text { Zoo (Narshiruddullah \& Chakraborty 2001) }\end{array}$ \\
\hline Leopard & Necropsy & Nandankanan Zoo (Rao \& Acharjyo 1993), Birsa Biological Park (Haque \& Ahmed 2002) \\
\hline
\end{tabular}

Table 5. Reports of various nematode parasitic infections in wild felids

\begin{tabular}{|c|c|c|c|}
\hline Species of the parasite & $\begin{array}{l}\text { Species of the } \\
\text { animal }\end{array}$ & $\begin{array}{l}\text { Procedure of } \\
\text { recovery }\end{array}$ & Locality (Reference) \\
\hline \multirow{2}{*}{ Filaroides osleri } & Leopard Cat & Necropsy & Nandankanan Zoo (Rao et al. 1971; Rao \& Acharjyo 1984) \\
\hline & Leopard & Necropsy & Bannerghatta Biological Park (Chandranaik et al. 2005) \\
\hline \multirow{3}{*}{ Galonchus perniciosus } & Jungle Cat & Necropsy & Maharajbagh (Dakshinkar et al. 2001) \\
\hline & Lion & Coprology & Baranga Zoo (Patnaik \& Acharjyo 1970) \\
\hline & Leopard & Necropsy & Baranga Zoo (Patnaik \& Acharjyo 1970), Thiruvananthapuram (Pythal et al. 1993) \\
\hline $\begin{array}{l}\text { Gnathostoma } \\
\text { spinigerum }\end{array}$ & Royal Bengal Tiger & Necropsy & $\begin{array}{l}\text { Assam State Zoo (Nashiruddullah \& Chakraborty 2001), Vandaloor Zoo (Thilakan et al. } \\
\text { 2007), Pench Tiger Reserve (Shrivastava et al. 2011) }\end{array}$ \\
\hline \multirow{2}{*}{ Strongyloides sp. } & Royal Bengal Tiger & Coprology & Thiruvananthapuram Zoo (Varadharajan\&Pythal 1999) \\
\hline & Leopard & Coprology & Thrissur Zoo (Varadhrajan et al. 2001) \\
\hline $\begin{array}{l}\text { Bronchostrongylus } \\
\text { subcrenatus }\end{array}$ & Royal Bengal Tiger & Necropsy & Assam State Zoo (Nashiruddullah \& Chakraborty 2001) \\
\hline Spirocerca lupi & Royal Bengal Tiger & Coprology & Maharajbagh Zoo, Nagpur (Dhoot et al. 2002) \\
\hline Capillaria aerophila & Royal Bengal Tiger & Necropsy & Assam State Zoo (Nashiruddullah \& Chakraborty 2001) \\
\hline Physaloptera sp. & Royal Bengal Tiger & Coprology & Nandankanan Zoo (Mahali et al. 2010) \\
\hline Ollulanus tricuspis & Royal Bengal Tiger & Necropsy & Sundarbans forest (wild), West Bengal (Mandal \& Chaudhury 1985) \\
\hline Trichuris sp. & Royal Bengal Tiger & Necropsy & Jim Corbett National Park (Arora \& Das 1988) \\
\hline
\end{tabular}

been found in wild felids including the Golden Cat, Royal Bengal Tigers, Asiatic Lions and Leopards. Reports of $D$. immitis infections in wild felids are listed in Table 4.

\section{Other nematode infections}

A number of other nematode parasites were less frequently recorded from wild felids. Baylis \& Dubney (1922) reported Galonchus pernicious, a new species of hookworm from a leopard and this species was also found in the intestines of a lion cub (Patnaik et al. 1971). Eggs of spirurids and Capillaria species were found on faecal examination at Coimbatore and Thrissur (Varadhrajan et al. 2001). The only acanthocephalan from felids, an Oncicola species, was recorded in Assam (Patnaik \& Acharjyo 1970). A list of parasites found sporadically and their hosts and the places of recovery is given in Table 5 .

\section{TREMATODE INFECTIONS \\ Paragonimus infections}

The most commonly encountered trematode infection in free-living and captive wild felids is paragonimiasis. Paragonimus was generally found embedded in cysts in the lung parenchyma and rarely caused the death of the infected animal. Histopathology showed bronchial hyperplasia due to mononuclear cell infiltration under the epithelial lining (Parihar \& Shrivastava 1988). At Nandankanan Zoo, a necropsied Golden Cat and Royal Bengal Tiger were found to be infected with Paragonimus westermani (Rao \& Acharjyo $1984,1991)$. Cysts containing one or more reddish oval shaped flukes were macroscopically observed in one or both lungs in combination with patches of atelectasis and emphysema (Rao \& Acharjyo 1991). P. westermani was also found during necropsies of tigers from different parts of the country including Corbett National Park in Uttar Pradesh (Arora \& Das 1988), Kanha National Park in Madhya Pradesh (Parihar \& Shrivastava 1988), 
Vandalur Zoological Park in Tamil Nadu (Latha et al. 2000) and Assam State Zoo in Guwahati (Nashiruddullah \& Chakraborty 2001). The species was also reported from a Clouded Leopard by Hiregoudar \& Pethkar (1970) and was found in a Leopard during post mortem and coprological examination in Thiruvananthapuram Zoo (Pythal et al. 1993; Varadhrajan \& Pythal 1999).

Sano et al. (1994) recovered Paragonimus eggs from four tigers and one Jungle Cat at Kanha National Park. These eggs differed from the eggs of $P$ westermani and raised the question of the existence of a new species of Paragonimus in India.

In 1970, the trematode Euparyphium malayanum was found at the necropsy of a Jungle Cat in Baranga Zoo in Odisha (Patnaik \& Acharjyo). Coprological evidence of Euparyphium species was also found recently in Nandankanan Zoo (Mahali et al. 2010). Nanophyetes salmincola was identified in faecal examinations of lions and leopards at Maharajbagh Zoo in Odisha (Dhoot et al. 2002) and Schistosoma species eggs were found during faecal examination of lions at Nandankanan Zoo in Odisha (Mahali et al. 2010). Clinical cases of schistosomiasis were reported from lions of Maharashtra (Shrikhande et al. 2002).

\section{Cestode infections}

The most common cestode infection encountered in wild felids was echinococcosis. Both adult and metacestode stages were recovered from captive and rescued free-ranging wild felids. The adult stages cause catarrhal enteritis in wild animals and the parasite deserves particular attention due to its significant zoonotic potential (Acharjyo 2004). Easwaran et al. (2003) found Echinococcus granulosus and Taenia species during necropsies in Leopard Cats at Thekkady in Kerala. Pande et al. (1970) recorded Spirometra species from the lions of the zoological garden of Lucknow. Taenia pisiformis and Spirometra erinaceae were the two cestode species reported in Bengal Tigers at Baranga Zoo (Patnaik \& Acharjyo 1970) and Taenia taeniformis was reported from the tigers of Corbett National Park (Gaur et al. 1980). Sharma et al. (1983) found Taenia jaipurensis in lions in India. Diphyllobothrium species infection was recorded during the post mortem of a male leopard at Thiruvananthapuram Zoo (Varadhrajan \& Pythal 1999). Diphyllobothrium latum was the most common species of cestode reported at faecal examination of leopards and was found at several places, for example, in Thrissur (Varadharajan et al. 2001) and Maharajbagh zoo in Nagpur (Dhoot et al. 2002). Fecal examination of a Leopard cub from Baranga
Zoo identified another cestode, Mesocestoides lineatus (Patnaik \& Acharjyo 1970). Spirometra erinaceae was reported at a necropsy from a Jungle Cat in Baranga Zoo (Patnaik \& Acharjyo 1970) and unidentified Spirometra species were reported from tigers at Vandalur (Latha et al. 2000) and leopards at Rajkot Zoo (Parsani et al. 2001) and Maharajbagh Zoo (Gawande et al. 2007). Recently, Taenia taeniaeformis and Spirometra mansonoides were recovered during the necropsy of a leopard found in a forest near Shimoga in Karnataka (Ananda et al. 2011) and Hymenolepis and Dyphyllobothrium species were identified from faecal samples at Thrissur Zoo (Varadharajan et al. 2001). Recently, Joyeuxiella pascalei was reported at a necropsy from a Jungle Cat at Puducherry (Das et al. 2011). Cases of hydatidosis were found in lions and jaguars at necropsy at Nagpur zoo (Ganorkar et al. 1997) and Chennai Zoological Park (Sathasivam et al. 2009), respectively.

\section{PROTOZOAN INFECTION IN WILD FELIDS}

The most common protozoan infections reported in wild felids are trypanosomiasis, babesiosis and coccidiosis. Large cats, mainly tigers, are frequently infected with T. evansi (Acharjyo 2000) and the reported signs include anorexia, pyrexia, panting, occasional convulsions and sudden death (Chaudhury et al. 1986; Devasena \& Shobhamani 2006). The various protozoan infections reported are listed in Table 6.

\section{ECTOPARASITIC INFECTION IN WILD FELIDS}

Fleas, ticks and mites are the ectoparasites reported in wild felids in India. Ticks, mainly Haemaphysalis spp., were reported by Geevarghese et al. (1997) and the main tick species reported were $H$. cuspidata on leopards, $H$. silvafelis on Jungle Cats and $H$. kinneari on tigers. Amblyomma hebraeum and another unidentified Amblyomma species were reported on tigers in Assam Zoo in two separate studies by Geevarghese et al. (1997) and Nashiruddullah \& Chakraborty (2001). Sarcoptes scabei infection was reported in lions of Bikaner Zoo (Gaurav \& Singh 1999) and infestation of Leopard Cats with Ctenocephalides felis felis was reported by Islam (2010).

\section{TREATMENT OF PARASITIC INFECTIONS}

The therapeutic management of parasitic infections in captive wild felids mainly consists of drug application targeting the specific parasite. Ivermectin was used to treat a mixed infection of Toxocara, Ancylostoma and tapeworm in Sundarban tigers brought to Alipur Zoo (Sur et al. 2001). Ivermectin was also used to treat 
Table 6. Reports of protozoan parasitic infection of wild felids

\begin{tabular}{|l|l|l|l|}
\hline $\begin{array}{l}\text { Species of the } \\
\text { parasite }\end{array}$ & $\begin{array}{l}\text { Species of the } \\
\text { animal }\end{array}$ & Diagnosis based on & Locality (Reference) \\
\hline \multirow{4}{*}{$\begin{array}{l}\text { Trypanosoma } \\
\text { evansi }\end{array}$} & Jungle Cat & Blood smear examination & Maharajbagh Zoo (Dakshinkar et al. 2002), Nandankanan Zoo (Sahoo et al. 2009) \\
\cline { 2 - 4 } & Tigers and cubs & Blood smear examination & National Circus at Kakinada, Andhra Pradesh (Rao et al. 1995) \\
\cline { 2 - 4 } & Tigers & Blood smear examination & Nandankanan Zoo (Parija \& Bhattacharya 2001) \\
\hline \multirow{3}{*}{ Babesia species } & Tigress & Blood smear examination & Ranchi Zoo (Sinha et al. 2000) \\
\cline { 2 - 4 } & Tigers & Blood smear examination & MC Zoological Park (Misra et al. 2008) \\
\cline { 2 - 4 } & Leopards & Blood smear examination & Nagpur Zoo (Upadhye \& Dhoot 2000) \\
\cline { 2 - 4 } & Tigers and lions & Coprology & $\begin{array}{l}\text { Lucknow Zoo (Chauhan et al. 1973), Mysore Zoo (Muraleedharan \& Iswariah 1984), MC } \\
\text { Zoological Park (Singh et al. 2006), Nandankanan Zoo (Mahali et al. 2010) }\end{array}$ \\
\hline Isospora felis & Leopards & Coprology & $\begin{array}{l}\text { Lucknow Zoo (Agrawal et al. 1981), Nandankanan Zoo (Mahali et al. 2010), Kerala Zoo } \\
\text { (Ravindran et al. 2011) }\end{array}$ \\
\hline \multirow{2}{*}{ Isospora species } & Fishing Cat & Coprology & Mathura (Agrawal \& Chauhan 1993) \\
\hline Isospora viverrina & & \\
\hline
\end{tabular}

toxocariasis in lions, which proved resistant to piperazine at MC Zoological Park (Singla et al. 2003).

Singh et al. (2006) used piperazine adipate and pyrantel pamoate to control Toxocara cati, Toxascaris leonina and hookworm infections in tiger cubs, adult tigers, lion cubs and treated panthers and leopards infected with hookworms with ivermectin. Amongst these drugs piperazine adipate was the most effective in controlling ascarids and 30 days after treatment the animals were parasite free. However in lions treated with pyrantel pamoate, $T$. leonina was recorded again 30 days after the treatment demonstrating its inefficacy to control the parasitic infection. Similarly, Dehuri et al. (2013) found ivermectin ineffective in the control of ascarids and hookworms in lions and reported reoccurrence of the parasites only a few days after treatment.

Triquin (quinapyramine sulphate and quinapyramine chloride) was used successfully to treat trypanosomiasis in wild felids (Gupta et al. 2009; Sahoo et al. 2009). Despite a thorough literature search we found that no successful treatment of babesiosis in wild felids was reported. And though ticks are commonly found on wild felids, their distribution, prevalence or treatment has not yet been studied comprehensively in India.

\section{CONCLUSIONS}

Parasitic disease studies of wild felids are not only important with respect to the animal's health but also important for their zoonotic potential. At present there is an information gap. A detailed epidemiological study targeting parasites of the felids should be carried out to obtain a clear picture of parasitism in India. Regular faecal examinations should be supported and supplemented with post mortem findings. Identification of the parasites and diagnosis of parasitic diseases needs to be improved using molecular techniques and the pathophysiology of several helminthic species. Administration of effective drugs with wide safety margins targeting a specific parasitic species and better management practices such as routine cleaning and disinfection, correct disposal of waste and clean food presentation should be adopted wisely, as all play important roles in reducing parasite infections in captive wild animals.

\section{REFERENCES}

Acharjyo, L.N. (2000). Incidence of parasitic diseasees among wild mammals and their control in Indian zoos. Lead Paper. Eleventh National Congress of Veterinary Parasitology, Bhubaneshwar, 4-6 February, 10-26pp.

Acharjyo, L.N. (2002). Helminthiasis in wild carnivores and its control. Lead Paper. Thirteenth National Congress of Veterinary Parasitology, Kolkata, 14-16 December, 6-19pp.

Acharjyo, L.N. (2004). Helminthiasis in captive wild carnivores and its control in India. Review. Zoos' Print Journal 19(7): 1540-1543; http://dx.doi.org/10.11609/JoTT.ZPJ.1001.1540-3

Agarwal, R.D. (1985). Studies on the parasitic fauna of zoo animals and wildlife: studies on the cercarial fauna of Mathura District with special reference to furcocerous cercariae. PhD Thesis, C.S.A. University of Agriculture, Kanpur.

Agrawal, R.D. \& P.P.S. Chauhan (1993). On a new coccidium Isospora viverrina from Fishing Cat (Felis viverrina). Indian Journal of Animal Sciences 63: 628-629.

Agrawal, R.D., S.S. Ahluwalia, B.B. Bhatia \& P.P.S. Chauhan (1981) Note on mammalian coccidia at Lucknow Zoo. Indian Journal of Animal Sciences 51: 125-128.

Agrawal, R.D. \& P.P.S. Chauhan (2001). On the occurrence of Ancylostoma duodenale and $A$. paraduodenale in a Lion (Panthera 
leo). Journal of Veterinary Parasitology 15: 59-62.

Ananda, K.J., B.K. Rani, K. Ramesha, M.J. Swethashree, V.H. Ranjitha, K.H. Nagaraj \& R.V. Prasad (2011). Tapeworm infection in a leopard: A case report. Compendium. 21st National Congress of Veterinary parasitology, Mumbai, 5-7 January, 2011, 125p.

Arora, B.M. \& S.C. Das (1988). Helminth infections in a tigress (Panthera tigris). Indian Journal of Veterinary Medicine 8: 154-156.

Baylis, H.A. \& R. Dubney (1922). Report on the parasitic nematodes in the collection of zoological survey of India. Memorandum of Indian Museum 7: 264-342.

Biocca, E. (1951). On Ancylostoma paraduodenale, a new species from felines, closely related to Ancylostoma duodenale. Journal of Helminthology 25: 11-18.

Chandranaik, B.M., S. Murthy, D. Das, G.S. Mamatha, C. Renukaprasad \& G. Krishnappa (2005). Helminthiasis in Leopards (Panthera pardus) at Bannerghatta Biological Park. Zoos' Print Journal 20(7): 1934; http://dx.doi.org/10.11609/JoTT.ZPJ.1284.1934

Chauhan, P.P.S., B.B. Bhatia, G.S. Arora, R.D. Agrawal \& S.S. Ahluwalia (1973). A preliminary survey of parasitic infections among mammals and birds at Lucknow and Delhi Zoos. Indian Journal of Anima Sciences 43: 163-68.

Chaudhury, C., B. Narasimhaswami, J. Heraramdas, P.B. Rao \& M.R.K. Rao (1986). A case of sudden death in a male tiger cub (Panthera tigris) with trypanosomiasis - a note. Indian Veterinary Journal 63: 506-507.

Chhabra, M.B. \& K.M.L. Pathak (2013). Parasites and Parasitic diseases of wildlife in India. 2. Carnivores and birds. Indian Journal of Animal Sciences 83: 567-578.

Dakshinkar N.P., V.M. Dhoot, S.V. Upadhye, G.R. Bhojne, D.B. Sarode \& S.W. Kolte (2001). Clinical report of Filaroides osleri infection in a Jungle Cat. Indian Veterinary Journal 78: 1068- 69.

Dakshinkar, N.P., V.M. Dhoot, S.V. Upadhye, G.R. Bhajne, D.B. Sarode \& S.W. Kolte (2002). Trypanosomiasis in a Jungle Cat. Indian Veterinary Journal 79: 66-67

Devasena, B. \& B. Shobhamani (2006). Trypanosomiasis in a tigress. Intas Polivet 7: 117.

Dehuri, M.M.R., Panda, B.N. Mohanty \& N. Sahoo (2013). Prevalence and evaluation of anthelmintics against nematodes in Lions (Panthera leo) in Nandankanan Zoo. Journal of Wildlife Research 1: 5-7.

Dhoot, V.M., S.V. Upadhye \& S.W. Kolte (2002). Prevalence of parasitism in wild mammals and birds of Maharajbag Zoo, Nagpur. Indian Veterinary Journal 79: 225-227.

Easwaran, K.R., R. Ravindran \& K.M. Pillai (2003). Parasitic infections of some wild animals at Thekkady in Kerala. Zoos' Print Journal 18(2): 1030; http://dx.doi.org/10.11609/JoTT.ZPJ.18.2.1030

Ganorkar, A.G., S.W. Kolte \& N.V. Kurkure (1997). Occurrence of hydatid cysts in a lion. Indian Journal of Veterinary Pathology 21: 64.

Gaur, S.N.S., M.S. Sethi, H.C. Tewari \& O. Prakash (1979). A note on the prevalence of helminth parasites in wild and zoo animals in U.P. Indian Journal of Animal Sciences 49: 159-161.

Gaur, S.N.S, H.C. Tewari, M.S. Sethi \& O. Prakash (1980). Helminth parasites from Tiger (Panthera tigris) in India. Indian Journal of Parasitology 4: 71-72.

Gaurav \& N.M. Singh (1999). Efficacy of ivermectin against Sarcoptes scabiei in African lion. Indian Veterinary Journal 76: 448-449.

Gawande, P.J., B.S. Baviskar, D.K. Maske, A.K. Jayraw \& S.W. Kolte (2007). A note on occurrence of Spirometra infection in leopard Panthera pardus from Nagpur region. Zoos' Print Journal 22(6): 2737; http://dx.doi.org/10.11609/JoTT.ZPJ.1710.2737

Geevarghese, G., S. Fernandez \& S.M. Kulkarni (1997). A checklist of Indian ticks (Acarina: ixodoida). Indian Journal of Animal Sciences 67: 566-574

Gupta, A., K. Jadhav, J.S. Chauhan \& P. Nigam (2009). Management of trypanosomiasis in a Tigress Panthera tigris: a case report. Journal of Threatened Taxa 1(10): 538-540; http://dx.doi.org/10.11609/ JoTT.02197.538-40

Gupta, M.K., K.D. Prasad, K.K. Singh \& S. Haque (1999). Occurrence of dirofilariosis in lions and tigers. Journal of Veterinary Parasitology
13: 77-78.

Haque, S. (2007). Recent advances in studies on babesiosis in big cats (tigers and leopards), pp. 47-48. In: Proceedings International Congress on Advances in Zoo and Wild Animal Helath and Management. Faculty of Veterinary Sciences and Animal Husbandry. SKUAST, Jammu, India.

Haque, S. \& A. Ahmad (2002). Comparative study of Diethylcarbamazine and Ivermectin on heartworms in pet and zoo animals. Veterinary Practitioner 3: 133-134.

Hiregoudar, L.S. \& D.K. Pethkar (1970). Paragonimus westermani from a clouded leopard in India. Gujvet 4(2): 84-86.

Islam, S. (2010). Parasites of Wildlife. In: Compendium XXth National Congress of Veterinary Parasitology, Hisar, 18-20 February, 45pp.

Khatun, M.M., N. Begum, M.A.A. Mamun, M.M.H. Mondal \& M. Shakif-ul-Azam (2014). Coprological study of gastrointestinal parasites of captive animals of Rangpur recreational garden and zoo in Bangladesh. Journal of Threatened Taxa 6(8): 6142-6147; http:// dx.doi.org/10.11609/JoTT.o3093.6142-7

Kumar, B.V. \& A.N. Rao (2003). Influence of age on the prevalence of parasitic infections among the felids in Animal Reserve Centre at Vizag Zoo, Vishakhapatnam, Andhra Pradesh. Zoos' Print Journal 18: 11.

Latha, B.R., S. Ramesh, M.G. Janathangaraj \& C.J. Methew (2000). Concurrent Paragonimus and Spirometra infection in a tigress. Indian Journal of Veterinary Medicine 20: 96.

Mahali, A.K., D.N. Panda, M.R. Panda, B.N. Mohanty \& B. Sahoo (2010). Incidence and seasonal variation of gastro-intestinal parasitic infections in captive carnivores in Nandankanan Zoological Park, Orissa. Journal of Veterinary Parasitology 24: 111-115.

Maity, B., G. Chakraborty \& K.K. Pradhan (1994). Toxocariasis in a Snow Leopard (Panthera uncia). Indian Veterinary Journal 71: 8486.

Mandal, D. \& A. Choudhury (1985). Helminth parasites of wild tiger of Sundarbans Forest, West Bengal, India. Proc. Int. Symp. Dis. Zoo Anim. 27: 499-501.

Maplestone, P.A. (1939). A new species of Uncinaria Frohlich, 1789 (Nematoda) with a note on Uncinaria stenocephala (Raillet, 1884). Records of Indian Museum 41: 219-222.

Misra, A.K., H. Singh, J.R. Rao, A.K. Tewari, P.S. Banerjee, M.P. Singh \& D. Swarup (2008). Babesiosis in a tigress at the zoological park, Chhatbir, Chandigarh. Journal of Veterinary Parasitology 22: 5-7

Muoria, P.K., P. Muruthi, D. Rubenstein, N.O. Oguge \& E. Munene (2005). Cross-sectional survey of gastro-intestinal parasites of Grevy's Zebras in southern Samburu, Kenya. African Journal of Ecology 43: 392-395.

Muraleedharan, K. \& V. Iswaraiah (1984). Coccidial infection in tiger (P. tigris) cubs. Indian Journal of Parasitology 8: 285-286.

Nashiruddullah, N. \& A. Chakraborty (2001). Parasites of captive wild carnivores of Assam State Zoo. Intas-Polivet 2: 173-181.

Pande, B.P., B.B. Bhatia, P.P.S. Chauhan \& R.K. Garg (1970). Species composition of coccidian of some of the mammals and birds at the Zoological Gardens, Lucknow (Utter Pradesh). Indian Journal of Animal Science 40: 154-166.

Parihar, N.S. \& S.N. Shrivastava (1988). Bronchial hyperplasia in a tiger (Panthera tigris).Indian Journal of Animal Sciences 58: 230-233.

Parija, S.C. \& S. Bhattacharya (2001). The tragedy of tigers: Lessons to learn from Nandankanan episode. Indian Journal of Medical Microbiology 19: 116-118.

Parsani, H.R., R.R. Momin, M.G. Maradia \& V. Singh (2001). A survey of gastrointestinal parasites of captive animals at Rajkot Municipal Corporation Zoo, Rajkot, Gujarat. Zoos' Print Journal 16(10): 604606; http://dx.doi.org/10.11609/JoTT.ZPJ.16.10.604-6

Patnaik, M.M. \& L.N. Acharjyo (1970). Notes on the helminth parasites of vertebrates in Baranga zoo (Orissa). Indian Veterinary Journal 47: 723-30.

Pawar, R.M., U. Lakshmikantan, S. Hasan, A. Poornachandar, S. Shivaji (2012). Detection \& molecular characterization of ascarid nematode infection (Toxascarisleonina and Toxocaracati) in captive Asiatic Lions (Panthera leo persica). Acta Parasitologica 57: 67-73; 
http://dx.doi.org/10.2478/s11686-012-0012-y

Pythal, C., K.M. Pillai, C.G. Varghese \& T. Surendranathan (1993) Death of a wild Indian Leopard Panthera perdus fusca (Meyer) due to parasitism with the lung fluke Paragonimus westermanii (Kerbert, 1878) and the hookworm Galonchus perniciosus (Linstow, 1885). Kerala Journal of Veterinary \& Animal Sciences 24: 44-46.

Raja, M.M.R.U., A.R. Dey, N. Begum, U.K. Kundu \& F.A. Ashad (2014). Coprological prevalence of gastrointestinal parasites in carnivores and small mammals at Dhaka Zoo, Bangladesh. Journal of Threatened Taxa 6(3): 5574-5579; http://dx.doi.org/10.11609/ JoTT.03569.5574-9

Rao, A.T. \& L.N. Acharjyo (1984). Diagnosis and classification of common diseases of captive animals at Nandankanan zoo in Orissa (India). Indian Journal of Animal Health 2: 147-152.

Rao, A.T. \& L.N. Acharjyo (1991). Paragonimiasis in some wild carnivores at Nandankanan. Indian Veterinary Journal 68: 791.

Rao, A.T. \& L.N. Acharjyo (1993). Incidence of heartworm in captive wild carnivores. Indian Journal of Parasitology 17: 201-202.

Rao, A.T. \& L.N. Acharjyo (1995). Causes of mortality in carnivores other than felids at Nandankanan Zoo. Indian Veterinary Journal 72 918-921.

Rao, A.T., L.N. Acharjyo \& B.B. Bhatia (1971). A note on the histopathology of lungs of a leopard cat (Felisbengalensis) due to Filaroidesosleri(Cobbold, 1879) Skrjabin, 1933. Indian Journal of Animal Sciences 41: 844-46.

Rao, M.A.N. (1939). ArthrocephalusgambiensisOrtlepp 1925. Indian Journal of Veterinary Science 9: 37-38.

Ravindran, R., B. Lakshmanan, S. Anoop, T.S. Rajeev \& C.N. Dinesh (2006). Parasitic infection in captive lions (Panthera leo) at Waynad. Zoos' Print Journal 21(4): 2230; http://dx.doi.org/10.11609/JoTT. ZPJ.1438.2230

Ravindran, R., K.G.A. Kumar \& V.M.A. Gafoor (2011). Parasitic infections in wild animals of Kerala. Zoos' Print Magazine 26: 34.

Sathasivam, S., N.K. Pathan, K. Senthilkumar \& K.P.M. Perrumah (2009). Hydatidosis in a Jaguar (Panthera onca). Zoos' Print Magazine 24: 16.

Sahoo, N., P.K. Roy, R.K. Samantaray \& A. Das (2009). Treatment of trypanosomiasis in a Jungle Cat. Indian Veterinary Journal 86: 844845.

Sano, M., M.C. Agarwal, P.C. Kotwal \& R. Gopal (1994) Paragonimusinfection in the tigers at Kanha National Park. Journal of Parasitology and Applied Animal Biology 3: 115-116.

Sharma, S.A., A. Bhalya, A. Seth \& V.N. Kapoor (1983). Taeniajaipurensisn. sp. from lion, Panthera leo. Indian Journal of Parasitology 7: 71-73.

Shrikhande, G.B., D.K. Maske, S.W. Kolte \& K.P. Kashid (2002). Schistosomiasis in lions (Panthera leo persica): a report. Journal of Veterinary Parasitology 16: 72.
Shrivastava, A.B., K.P. Singh, M.A. Bhat \& A. Mishra (2011). Occurrence of Gnathostomaspinigerumin free range tigress. Journa of Parasitic Diseases 35: 75-76; http://dx.doi.org/10.1007/s12639011-0029-4

Singh, P., M.P. Gupta, L.D. Singla, N. Singh \& D.R. Sharma (2006). Prevalence and chemotherapy of gastrointestinal helminthic infections in wild carnivores of Mahendra Choudhury Zoolgoical Park, Punjab. Journal of Veterinary Parasitology 20: 17-23.

Singla, L.D., A. Kumar, G.S. Aulakh \& J. Singh (2003). Management of piperazine resistant toxocariosis with ivermectin in lions, p. 354. In: 3rd International Wildlife Management Congress (1-5 December 2003) Christchurch, New Zealand.

Sinha, K.P., M. Sinha, N.K. Pankaj \& V.K. Singh (2000). Babesiosis in a tigress. Zoos' Print Journal 15(8): 327; http://dx.doi.org/10.11609/ JoTT.ZPJ.15.8.327a

Sur, S.K., G.L. Ghosh \& D. Chatterjee (2001). Use of ivermectin in tigers for removing intestinal parasites. Zoos' Print Journal 16(1): 410; http://dx.doi.org/10.11609/JoTT.ZPJ.16.1.410

Suresh, K., P.C. Choudhuri, K.N. Kumari, Md. Hafeez \& P.A. Hamza (2000). Symptomatology and therapy of ancylostomiasis in Leopards. Zoos' Print Journal 15(8): 312-313; http://dx.doi. org/10.11609/JoTT.ZPJ.15.8.312-3

Tanwar, R.K., L.N. Mittal, S.N. Sharma, J.S. Yadav \& P.D. Mathur (1984). Parasitic gastritis in an Asian Lion - a case report. Indian Journal of Veterinary Medicine 4: 48-49.

Thawait, V.K., S.K. Maiti \& A.K. Dixit (2014). Prevalence of gastrointestinal parasites in captive wild animals of Nandan van zoo, Raipur, Chhattisgarh. Veterinary World 7: 448-451; http://dx.doi. org/10.14202/vetworld.2014.448-451

Thilakan, N.J., J. Selvaraj, S.S. Kumar, M.G.J. Thangaraj \& L. John (2007). Concurrent infection of Gnathostoma spinigerum and Ancylostoma braziliense in a tigress. Journal of Veterinary Parasitology 21: 191-192.

Upadhye, S.V. \& V.M. Dhoot (2000). Trypanosomiasis in a tiger (Pantheratigris). Zoos' Print Journal 15(8): 326; http://dx.doi. org/10.11609/JoTT.ZPJ.15.8.326

Varadharajan, A. \& A. Kandasamy (2000). A survey of gastro-intestinal parasites of wild animals in captivity in the V.O.C. Park and Mini Zoo, Coimbatore. Zoos' Print Journal 15(5): 257-258; http://dx.doi. org/10.11609/JoTT.ZPJ.15.5.257-8

Varadharajan, A. \& C. Pythal (1999). Parasites of wildlife-I. A preliminary investigation on the parasites of wild animals at the Zoological Garden, Thiruvananthapuram, Kerala. Zoos' Print Journal 14(12): 159-64; http://dx.doi.org/10.11609/JoTT.ZPJ.14.12.159-64

Varadharajan, A., C. Pythal \& H. Subramanian (2001). Investigation on the prevalence of helminth parasites of wild mammals in the Thrissur Zoo, Kerala. Cheiron 30: 12-15. 